\section{Intersections}

Canadian Journal of Music

Revue canadienne de musique
Intersections CANADIAN JOURAL OF MUSIC
REVUE CANADIENER DE MUSIQUE

\title{
Writing for CBC Wartime Radio Drama: John Weinzweig, Socialism, and the Twelve-Tone Dilemma
}

\section{Carolyne Sumner}

Volume 36, numéro 2, 2016

URI : https://id.erudit.org/iderudit/1051600ar

DOI : https://doi.org/10.7202/1051600ar

Aller au sommaire du numéro

\section{Éditeur(s)}

Canadian University Music Society / Société de musique des universités canadiennes

\section{ISSN}

1911-0146 (imprimé)

1918-512X (numérique)

Découvrir la revue

Citer cet article

Sumner, C. (2016). Writing for CBC Wartime Radio Drama: John Weinzweig, Socialism, and the Twelve-Tone Dilemma. Intersections, 36(2), 77-88. https://doi.org/10.7202/1051600ar

\section{Résumé de l'article}

Le drame radiophonique était le divertissement par excellence pour le public canadien pendant la deuxième guerre mondiale. La Société Radio-Canada (SRC) en a profité pour utiliser cette forme d'art à des fins de propagande et pour stimuler le soutien à l'effort de guerre. Semblablement, la dramaturgie radiophonique de la SRC est devenue une tribune essentielle permettant aux artistes et compositeurs d'exprimer à l'échelle nationale leurs convictions politiques. Cet article remet dans son contexte sociopolitique des années 1930 et 1940 le travail du compositeur canadien John Weinzweig pour la série dramatique de la SRC intitulée New Homes for Old (1941). On y propose que le drame radiophonique a offert à Weinzweig une tribune nationale à l'expression de ses idéaux socialistes radicaux pendant une période de bouleversement politique. Notre recherche prend le relais des travaux biographiques d'Elaine Keillor et Brian Cherney et s'appuie sur des documents d'archives de Bibliothèque et Archives Canada, des Archives musicales de Radio-Canada et du Concordia Centre for Broadcasting and Journalism Studies. Nous confirmons les liens de Weinzweig avec les milieux socialistes et nous avançons que ses sympathies politiques l'ont amené à simplifier son langage en faveur d'une esthétique moderne simplifiée, plaisant davantage au public conservateur canadien de ce temps de guerre. Notre étude de l'oeuvre radiophonique de Weinzweig montre comment ce dernier a cherché à composer une série d'oeuvres faciles d'accès, et comment il a intégré dans son langage musical des éléments plus courants tirés de chansons traditionnelles et d'hymnes nationaux pour lui donner un vernis davantage en phase avec l'esthétique européenne élitiste. Nous montrons en conséquence comment Weinzweig a utilisé un média puissant et omniprésent afin de promouvoir son style musical original et de diffuser les idéaux culturels, politiques, et esthétiques de la gauche socialiste.
Copyright ( C Canadian University Music Society / Société de musique des universités canadiennes, 2018
Ce document est protégé par la loi sur le droit d'auteur. L’utilisation des services d’Érudit (y compris la reproduction) est assujettie à sa politique d'utilisation que vous pouvez consulter en ligne.

https://apropos.erudit.org/fr/usagers/politique-dutilisation/ 


\title{
WRITING FOR CBC WARTIME RADIO DRAMA: JOHN WEINZWEIG, SOCIALISM, AND THE TWELVE-TONE DILEMMA
}

\author{
Carolyne Sumner
}

In 1941, the Canadian Broadcasting Corporation hired composer John Weinzweig to write original background music for wartime radio drama. As the first composer hired by the CBC for this purpose, Weinzweig had the unique and vital role of pioneering the genre of radio docudrama music in Canada. Scholars including Udo Kasemets and Elaine Keillor have briefly examined his compositions for radio, calling attention to his use of the twelve-tone technique in these works. Despite their claims, however, a closer examination of Weinzweig's manuscript scores for the CBC radio drama series New Homes for Old (1941) reveals that he uses a modified technique that differs from the twelve-tone approach and modernist language he uses in his concert music of the time. Although his decision to modify his serial approach in his radio works may have been prompted by a variety of circumstances, I believe that Weinzweig's engagement with leftist political ideals during the 1930 s and 1940 s was an important contributing factor.

Thus, in my article, I will frame Weinzweig's early career at the CBC in light of Canada's socio-political climate and the rise of leftist political movements, notably the Popular Front, during the interwar period. Drawing upon archival material, including original manuscript scores, radio scripts, program schedules, recordings, and biographical documents, I will suggest that Weinzweig's personal, artistic, and political ties with the radical left may have encouraged him to modify his modernist and serial language in these works in favour of a more accessible and simplified musical language that embodied the cultural, political, and aesthetic ideals of leftist socialism, while also embracing the populist values perpetuated by the Popular Front movement. In doing so, I propose that Weinzweig uses radio drama as an artistic outlet to express his leftist political ideals during the war. ${ }^{1}$

1 This conference paper is an abridged version of a forthcoming full-length article to be published in Les Cahiers de la Société Québécoise de Recherche en Musique 17 (2). 


\section{Radio Drama in Canada}

A popular form of entertainment that flourished in Canada during the early 1920 , radio drama is a theatrical medium that combines the musical, theatric$\mathrm{al}$, and literary arts and was created specifically for the art of radio broadcasting. During the Second World War, the production of radio drama in Canada increased significantly as the $\mathrm{CBC}$ began producing several popular new wartime radio dramas. These dramas lauded the Canadian war effort and were produced by the $\mathrm{CBC}$ in the hopes of maintaining civilian morale on the home front. As a result, many articulated strong patriotic, militaristic, and nationalist themes and were used as wartime propaganda by both the $\mathrm{CBC}$ and the government to promote national unity, boost morale, and educate Canadians about the war effort. ${ }^{2}$

Although radio drama became an important tool for disseminating wartime propaganda, it also became a significant socio-political outlet for wartime artists as well. Notably, the increased production of radio drama offered new creative opportunities for young Canadian artists and composers such as Weinzweig; working for the $\mathrm{CBC}$ not only offered them artistic and financial support, but it also granted them access to a national audience for their creative works. More importantly, however, it provided them with a new platform through which they could express, communicate, and disseminate their own socio-political views during the war.

As a radio drama composer, Weinzweig wrote over one hundred scores for several CBC wartime radio docudrama series, including Brothers in Arms, Canada Marches, Comrade in Arms, Our Canada, and The British Empire Series. ${ }^{3}$ His first radio commission, New Homes for Old, was written by CBC scriptwriter Alistair Grosart and produced by Ian Smith. It is an eleven-week series that depicts the lives of European immigrants who fled to Canada during the war. Based on factual accounts, this series ultimately explores the experiences, traditions, and aspirations of these "new Canadians" who immigrated from countries including Czechoslovakia, Russia, Germany, Ukraine, Poland, Austria, and the Netherlands. ${ }^{4}$

Weinzweig's experience writing for radio drama had a significant impact on his compositional language at the time and required him to adjust his approach to meet the constant demand for the production of incidental music for radio. Because most dramas were broadcast weekly, Weinzweig had limited time to write his scores. To prepare for his compositions, he was given a script that included musical cues indicating desired musical effects, entries, themes, or genres for each drama, providing him with rough guidelines for his creative task (Keillor 2011, 104). In addition, Weinzweig regularly met with production members (scriptwriter and director) to discuss his scores for each program to ensure that they complemented the expressive intent of the dramas. Once

2 For further information concerning the production of $\mathrm{CBC}$ radio drama in Canada, please see Fink (1976-7); Fink (1983); Stewart (1975).

3 Please see appendix section of Keillor (1994).

4 Alistair Grosart, script, John Weinzweig Fonds. "New Home for Old: Czechoslovakia” 1, Library and Archives Canada. 
completed, he rehearsed his scores with the studio orchestra (fifteen to twentyfive musicians) and conducted the live broadcasts of his compositions (ibid.).

While writing for radio drama was challenging for the young composer, it offered him the unique opportunity to pioneer a new genre of incidental music that suited the aesthetic needs of radio drama and the complexities of live radio broadcasting. Despite having to adjust his compositional approach, this experience helped him hone his orchestration skills, as he recollects: "Writing music for radio plays was an experience that taught me to meet deadlines, sharpen my orchestral craft, respond to dramatic situations with brevity, to be prepared for those last-second cuts in the script, and frequently, to say goodbye to a great music cue, and as well, to stay clear of complex fugal activity behind voices" (Weinzweig 1988, 79).

Writing for radio, therefore, granted Weinzweig new creative opportunities during a formative period of his compositional career. As I wish to show, however, his experience writing for wartime radio drama also had a significant impact on his musical language, particularly his use of the twelve-tone technique in these works. More significantly, I will consider how the political climate of this period and the rise of the Popular Front movement may have informed Weinzweig's compositional decisions at this time, specifically his adoption of simpler musical language and his use of a modified twelve-tone approach.

\section{The Popular Front}

Scholars interested in the relationship between music and politics have considered how the rise of the Popular Front movement in both Europe and North America had a significant impact on the compositional language and style of modern composers active during the interwar and Second World War period. Recognized as an international socio-political movement, the Popular Front emerged during the 1930 in response to the increased rise and threat of fascism (Crist 2005, 20). This movement united various groups, including unionists, socialists, communists, anti-fascists, émigrés, and activists and garnered significant support among artistic circles (Denning 2010, 4, xvi). As explained by cultural historian Michael Denning, this period was one of "extraordinary flowering of arts, entertainment, and thought," in which artists and intellectuals produced artistic works that embodied both the cultural politics and aesthetic ideologies perpetuated by the Popular Front movement (xvi).

Scholars including Carol Oja, Melissa De Graaf, Elizabeth Crist, and Gayle Murchison have examined how this political movement significantly impacted the compositional approach used by American modern composers during the interwar period (Oja 2000; De Graaf 2013; Crist 2003; Murchison 2012). Specifically, they note that these composers utilized their works as a means of musically representing their alliance with the political left, shifting their highly experimental style towards a simpler and more accessible musical language that embraced the Popular Front ideals of social relevancy and accessibility (De Graaf 2013, 78, 74). Composers including Charles Seeger, Henry Cowell, Ruth Crawford, Norman Cazden, and Aaron Copland are a few among many who 
simplified their modernist idiom and language in order to write more accessible works that appealed to the general public (Murchison 2012, 176, 151).

Although the socialist ideals promoted by the Popular Front were felt mostly in the United States and France, similar ideals also circulated among Canadian artistic and intellectual circles during the interwar period, encouraging many to create works that embraced or reflected the ideals of leftist socialism. ${ }^{5}$ In particular, the 1930s saw an increased rise in Canadian leftist art, including poetry, plays, novels, and artwork. While few scholars have investigated the impact of the Popular Front on Canadian composers during this period, the ideals perpetuated by this movement may have also informed the musical works of Canadian composers at this time. Specifically, it is likely that the socialist and populist values promoted by this movement resonated greatly with composers such as Weinzweig who were sympathetic towards the leftist and socialist cause, thus prompting them to create artistic works that embodied the political and cultural ideals advocated by the Popular Front.

\section{Writing for Radio Drama and the Twelve-Tone Dilemma}

As mentioned, scholars including Udo Kasemets and Elaine Keillor have briefly examined Weinzweig's compositions for radio, particularly his use of the twelve-tone technique in these works. As Kasemets claims, Weinzweig adopted the technique because "he felt the twelve-tone idiom suited perfectly the concise and descriptive needs of radio music" (1960, 12). Similarly, in her study of Weinzweig's early radio works, Keillor further highlights his use of the technique; as she notes, "By the early 1940s, he was using twelve-tone technique on a regular basis ... it is therefore no surprise to see in his notebook, among sketches for the program "Poland (1)" of New Homes for Old, the series G, C, F\#, F, A, D, G\#, E, B, B flat, E flat” (2011, 104).

Although Weinzweig includes this row in his pre-compositional material for Poland (notwithstanding the fact that the row consists of eleven tones, not twelve), there is no complete statement of the row in his finalized scores for this program. Rather, an examination of his completed manuscript score reveals that he used the tone row only as intervallic, melodic, and motivic inspiration, without presenting a complete statement of the row and its transformations. Examples include a reoccurring tetrachord motif, $\mathrm{B}-\mathrm{B}$ flat-A-E, which derives from the pre-compositional tone row indicated in his sketches, as first stated in measure one of "Poland (1)".

Despite the claims made by Kasemets and Keillor, Weinzweig's use of the technique in his work for radio is debatable, as further evidenced by his opening theme for New Homes for Old. The theme lacks a clear statement of a complete tone row, nor is there evidence suggesting the use of serial procedures including inversion, retrograde, retrograde-inversion, or transposition. Rather, it features distinctly tonal materials in which Weinzweig quotes and integrates motifs from the Canadian national anthem in measures four through six,

5 For further information on the artistic left in Canada during the interwar period, see Rifkin (2005). 
and later in measures twenty-one through twenty-three. While Weinzweig's sketches reveal his engagement with serial techniques in his pre-compositional materials, the lack of clearly stated row forms or serial procedures, as well as the integration of tonal materials in his completed scores for NHFO, further suggests that Weinzweig used the twelve-tone row only as melodic and motivic inspiration for his composition, with no intention to further elaborate these rows using serial transformations.

To further elucidate Weinzweig's questionable application of the serial technique in his works for radio, a brief discussion of his early serial influences and compositions is warranted. Weinzweig first adopted the technique while studying at the Eastman School of Music for his graduate studies in composition from 1937 to 1938, where he became acquainted with the twelve-tone works of Alban Berg and Arnold Schoenberg (Keillor 1994, 18). Of particular significance was Berg's Lyric Suite (1926), which had a lasting influence on Weinzweig's approach to serialism. A notable feature of the work includes Berg's idiosyncratic twelve-tone approach, in which he utilizes both free atonal and strict serial procedures (Ashby 2008, 184). As noted by Catherine Nolan, Weinzweig was particularly interested in Berg's emphasis on motivic relationships and his alteration of the row pitch ordering $(2011,131)$.

Weinzweig's exposure to Berg's Lyric Suite, as well as Schoenberg's piano works, informed his early approach to serialism. Composed in 1939, Suite for Piano No. 1 is not only Weinzweig's first serial work but is also considered the first serial piece written by a Canadian composer (Keillor 1994, 120). This work features distinct twelve-tone rows and serial procedures, as evidenced in the second and third movements of the piece. The second movement of the suite, "Dirgeling," features a twelve-tone row, which first appears in the lefthand melody, F sharp-C-B-B flat-E flat-A-A flat-D-F-D flat-E-G. In the third movement, "Themes with Variables," Weinzweig also features a complete twelve-tone set in the first section of this movement, C-G flat-G-B-B flat-E flat-A flat-D-D flat-F-E-A. In both of these movements, Weinzweig uses serial procedures, including inversion and retrograde, to transform his tone rows $(120-4)$.

Another significant source of influence that informed Weinzweig's early serial approach includes Ernst Krenek's Studies in Counterpoint Based on the Twelve-Tone Technique (1940). Here Krenek discusses the basic principles of the twelve-tone technique, while also proposing an alternative approach based on the principles of counterpoint. Specifically, Krenek explores the motivic possibilities of the twelve-tone row, in which the row acts as a "store of motifs ... which all the individual elements of the composition are to be developed upon," thus assuring consistency and continuity within the work (viii). Krenek's approach further emphasizes the importance of rhythmic and melodic integrity of the row and also delineates exceptions to the strict twelve-tone rule, such as the repetition of tones and adherence to the prime tone row order (3-4). Krenek's influence is evidenced in Weinzweig's serial works Rhapsody (1941) and Violin Sonata (1941), both of which were composed the same year he was commissioned to write incidental music for the CBC. Both works feature 
distinct twelve-tone rows that are elaborated using serial procedures such as retrograde, inversion, and retrograde inversion and also recall Krenek's emphasis on serially derived motives (Keillor 1994, 128, 131-3).

In comparison to his early serial works, therefore, it is evident that Weinzweig's use of the technique in his works for radio diverges significantly from the technique he uses in his concert works. Unlike his early serial compositions, Weinzweig's scores for NHFO do not feature distinct twelve-tone rows, nor do they exhibit the use of serial procedures. Rather, in these works Weinzweig appears to be using a simplified or modified version of the technique, one that gravitates towards motivic design and development. ${ }^{6}$

In considering the factors and circumstances that may have prompted Weinzweig to modify his serial language in his scoring for radio drama, it is possible that he was persuaded, or perhaps pressured, by CBC staff members, conductors, and musicians to alter his aesthetic to make his score both more playable and accessible. Similarly, it is also possible that Weinzweig had to modify his approach to suit the technological and aesthetic demands of live radio broadcasting, including time constraints, and writing appropriate background music that both suited the technology of the microphone and did not overpower the voice actors during live broadcasts. Lastly, Weinzweig may have also simplified his modern language to appeal to conservative Canadian listeners of the time who were not yet accustomed to the sounds and idioms of modernism.

While these circumstances possibly played a role in Weinzweig's decision to modify his serial language in these works, it is important to consider how the broader socio-political climate that framed the formative years of his career may also have prompted him to temper his modern compositional language. Specifically, some consideration of Weinzweig's personal ties with radical socialism and the Popular Front may help elucidate his idiosyncratic use of the technique in his incidental scores for radio. More importantly, some consideration of how his early and continued exposure to radical socialism while living in Toronto's leftist Jewish community may further reveal how his engagement with these ideals encouraged him to use a more accessible and palatable serial language, one that embodied leftist and socialist ideals circulating in Canada during the 1930 and 1940 os.

\section{Weinzweig and the Political Left}

Born in 1913 to Polish immigrant parents, Weinzweig grew up above his father's garment shop on College Street in Toronto's Jewish neighbourhood (Keillor 1994, 6). During the early twentieth century, Toronto became an important hub for Jewish immigrants, many of whom carried their socialist ideals and beliefs

6 While Weinzweig's idiosyncratic approach to the serial technique was informed by the techniques used by Berg and Krenek, this author acknowledges that Weinzweig's technique may have also been influenced by the works and approaches used by American serial composers at this time. The American serial influence has not been explored here in depth but has been addressed at length in other publications (Sumner 2016; Sumner forthcoming). 
with them to Canada (Wolters-Fredlund 2002, 20). This led to the development of trade unions and socialist Jewish fraternal organizations that promoted Yiddish culture and tradition, the largest being the Workmen's Circle (established in 1908) (ibid.). These organizations established children's schools, including the Workmen's Circle Peretz school, which Weinzweig attended in his youth during the 1920 (ibid.). As Brian Cherney explains, the Peretz School, built by former members of the Bund (a secular Jewish socialist party), was dedicated to the "improvement in conditions for the working class and the perpetuation of Jewish history and culture" (Keillor 1994, 6-7; Cherney 2011, 51). According to his childhood piano teacher, Gertrude Anderson, it was while attending Peretz that Weinzweig "was taught to think clearly and independently along political and social lines and incidentally, he imbibed here certain socialist ideas" (Cherney 2011, 51).

Although Weinzweig was exposed to radical socialist ideals at the Peretz School, he was also likely introduced to radical socialist ideals by his father, Joseph Weinzweig. Affiliated with the Bund, Joseph was incarcerated for his involvement in Bund activities prior to his arrival in Canada (Keillor 1994, 5). According to Cherney, Joseph would have carried his Bundist and leftist beliefs with him to Canada and shared them with his son. As he explains, it was not uncommon for Jewish immigrant parents who practised radical socialism to bring their children to socialist meetings and demonstrations (Cherney 2011, 51). As Cherney further reveals, Joseph's association with the Bund had a lasting impact on Weinzweig, noting that he identified strongly with his father's political activities in Poland, thus suggesting that he espoused leftist and socialist political values similar to his father's (ibid.).

In addition to his educational and familial ties to radical socialism, it is also important to consider how Weinzweig's artistic surroundings during the interwar period may have also informed his political and artistic views. John Beckwith notes that, while living in Toronto, Weinzweig was influenced by leftist artists: "A sympathizer, though not an activist, [Weinzweig] was affected by the leftist politics of Toronto artists and writers in the between-war era" (1997, 180). This likely includes the prominent Toronto Jewish Folk Choir, which became the voice for leftist ideals and assumed an important political identity during the late 1930 s and early 1940 os, performing works that supported socialist ideals (Wolters-Fredlund 2002, 21-4). Lastly, it is also important to consider Weinzweig's political affiliations during the 1940s, notably his ties with the National Council for Canada-Soviet Friendship. According to Cherney, Weinzweig may have been an active member of this organization during the 1940s, as evidenced in a dedication for his piece Fanfare, which was performed for a concert sponsored by the organization during the Congress of Canada-Soviet Friendship in Toronto in $1943(2011,59)$.

While this biographical evidence demonstrates how Weinzweig likely imbibed radical socialist (and even communist) values circulating in Toronto during the 1930s and 1940s, it does not elucidate how his musical works were influenced by these ideals. Thus I will briefly contemplate how the leftist Popular Front ideals of populism may have informed Weinzweig's decision to 
simplify his serial language and to incorporate vernacular and tonal materials in his incidental scores for New Homes for Old.

\section{Writing for the "People”: WeinzWeig ANd Simplified SERIALISM}

As described by Denning, populism was a central trope of leftist socialism during the 1930s, one that "dissolved a politic of class conflict, of workers mobilization and self-organization, and obscured the divisions of ethnicity, race, and gender in an imagined unity of the 'people' and the 'people's culture"' (Denning 2010, 124). The values advocated by Popular Front ideals of populism encouraged several composers of the time, particularly modern American composers such as Aaron Copland, to temper their modernist musical language in favour of a more accessible, comprehensible, and socially relevant musical language and to create works that would appeal to the "people" (Murchinson 2012, 1756). Notable characteristics of the simplified idiom used by these composers includes reducing the density of musical textures, tempering dissonant harmonies, and simplifying rhythms (151). Similarly, another important feature of the simplified idiom includes the quotation and integration of vernacular idioms, particularly folk tunes and melodies (ibid.). As used by a composer such as Copland, the incorporation of folk songs not only made modern works more accessible, relatable, and familiar but also reflected the ideals of populism and the aesthetic trope of the "people's culture" (Reuss and Reuss 2000, 130).

It is possible, therefore, that Weinzweig was persuaded by similar Popular Front ideals, prompting him to simplify his serial and modern language in his radio works to make what was once a highly inaccessible, elite, and bourgeois musical language accessible to the average Canadian listener, to the everyday "people." As his work for New Homes for Old reveals, Weinzweig not only adopts a musical language that is essentially tonal and familiar, but he also uses musical elements, techniques, and materials that reflect the simplified aesthetic adopted by leftist artists and intellectuals who were creating artistic works reflective of the "people" and for the "people." Specifically, Weinzweig's scores reveal a gravitation toward simpler melodies, milder dissonances, and straightforward rhythms (without completely forsaking his commitment to modernism), as exemplified in his opening theme for the series.

A prevalent feature of the simplified aesthetic adopted by Weinzweig is the use of folk and vernacular idioms. Weinzweig draws upon the traditional music and folk tunes from various countries, including Polish hymns and dances, Yugoslavian tunes, and Czechoslovakian melodies (Keillor 2011, 105). Similarly, his scores also reveal his inclusion of popular and recognizable genres including dances, chants, fanfares, and marches, as seen in his score for the sixth program of the series "Russia." These materials, such as the traditional Polish hymn tune Boze Cos Polske, which appears in the "Poland" program, provides Weinzweig with important reoccurring thematic material for his scoring.

Another important vernacular idiom Weinzweig utilizes in his scoring for $N H F O$ is the national anthem. Notably, Weinzweig quotes the national anthems 
from various countries in his incidental scores, including the Austro-Hungarian anthem and the imperial Russian anthem. While he utilizes and quotes anthems in his scoring for the series, Weinzweig emphasizes and draws upon the Canadian anthem most frequently. In particular, the Canadian anthem becomes an important motivic and thematic element in his scores, and, as Keillor explains, he would integrate and blend motifs from the national anthem into his twelve-tone technique, as seen in the opening theme for the series (Keillor 1994, 124). It can be argued, however, that his use of the Canadian anthem in his scoring for NHFO further emphasizes the populist quality of his scoring for the series; not only was it highly familiar to Canadian listeners, but it was also musically representative of the Canadian people. In doing so, Weinzweig's scoring not only reflected the essence of the Canadian people tuning in to this drama; but moreover, it embraced the arrival of the "new" Canadians portrayed in these dramas.

While this article provides only a brief glimpse into Weinzweig's work for wartime radio drama, it sheds a necessary light on one of the most prolific and fruitful periods of his career and also demonstrates how his political values and affiliations may have significantly affected his compositional decisions at this time. Specifically, it has shown how Weinzweig's early and continued exposure to radical socialist ideals may have prompted him to modify his serial technique in favour of a simplified musical language that embraced the contemporary ideals of leftist socialism and Popular Front ideals of populism. More importantly, however, this article has shown how working for the $\mathrm{CBC}$ during the war not only helped him acquire a national audience for his works but also ultimately provided him with an artistic outlet through which he could safely express and voice his political views.

\section{REFERENCES}

\section{Music Scores}

Weinzweig, John. 1941a. New Homes for Old, "Czechoslovakia." -1941b. New Homes for Old, "Poland (1)." 1941c. New Homes for Old, "Russia."

\section{Primary Sources}

Grossart, Allistair. Script. John Weinzweig Fonds. "New Homes for Old: Czechoslovakia." Library and Archives Canada, Ottawa.

\section{Secondary Sources}

Ashby, Arved. 2008. “The Lyric Suite and Berg's Twelve-Tone Duality.” Journal of Musicology 25 (2): 183-210.

Beckwith, John. 1997. Music Papers: Articles and Talks by a Canadian Composer, 1961-1994. Ottawa: Golden Dog, 1997.

Cherney, Brian. 2011. "The Activist." In Weinzweig: Essays on His Life and Music. Edited by John Beckwith and Brian Cherney, 47-73. Waterloo, ON: Wilfrid Laurier University Press. 
Crist, Elizabeth B. 2003. "Aaron Copland and the Popular Front." Journal of the American Musicological Society 56 (2): 409-65.

.2005. Music for the Common Man: Aaron Copland during the Depression and War. New York: Oxford University Press, 2005.

De Graaf, Melissa. 2013. The New York Composers' Forum Concerts, 1935-1940. Rochester, NY: University of Rochester Press.

Denning, Michael. 2010. The Cultural Front: The Laboring of American Culture in the Twentieth Century. New York: Verso.

Fink, Howard. 1976-7. "The CBC Radio Drama Project and Its Background." Oral History Forum / Forum d'Histoire Orale 2:54-63.

-1983. Canadian National Theatre on the Air, 1925-1961: CBC-CRBC Radio Drama in English, a Descriptive Bibliography and Union List. Toronto: University of Toronto Press.

Kasemets, Udo. 1960. "John Weinzweig." Canadian Music Journal 4 (4): 4-18.

Keillor, Elaine. 1994. John Weinzweig and His Music: The Radical Romantic of Canada. Metuchen, NJ: Scarecrow.

_. 2011. "Music and Radio and Film." In Weinzweig: Essays on His Life and Music, edited by John Beckwith and Brian Cherney, 103-29. Waterloo, ON: Wilfrid Laurier University Press.

Krenek, Ernst. 1940. Studies in Counterpoint Based on the Twelve-Tone Technique. New York: G. Schirmer.

Murchison, Gayle. 2012. The American Stravinsky: The Style and Aesthetics of Copland's New American Music, the Early Works, 1921-1938. Ann Arbor, MI: University of Michigan Press.

Nolan, Catherine. 2011. "The First Canadian Serialist." In Weinzweig: Essays on His Life and Music, edited by John Beckwith and Brian Cherney, 131-49. Waterloo, ON: Wilfrid Laurier University Press.

Oja, Carol J. 200o. Making Music Modern: New York in the 1920s. New York: Oxford University Press.

Reuss, Richard, and Joanne Reuss. 2000. American Folk Music and Left-Wing Politics, 1927-1957. Lanham, MD: Scarecrow.

Rifkin, Candida. 2005. "Modernism's Red Stage: Theatre and the Left in the 1930s." In The Canadian Modernists Meet, ed. Dean Irvine, 181-5. Ottawa: University of Ottawa Press.

Stewart, Sandy. 1975. A Pictorial History of Radio in Canada. Toronto: Gage Publishers.

Sumner, Carolyne. 2016. "John Weinzweig, Leftist Politics, and Radio Drama during the Second World War." MA thesis, University of Ottawa. -Forthcoming. "Radical Socialism, Simplified Serialism: John Weinzweig and CBC Wartime Radio Drama during the Second World War." Société Québécoise de Recherche en Musique 17 (2).

Weinzweig, John. 1988. "The Making of a Composer." Paper presented at the Celebration of Canada's Arts 1930-1970 conference, University of Victoria, February-March. 
Wolters-Fredlund, Benita. 2002. "Leftist, Jewish, and Canadian Identities Voiced in the Repertoire of the Toronto Jewish Folk Choir, 1939-1959." Canadian Journal for Traditional Music 29: 19-31.

\begin{abstract}
Radio drama was a quintessential source of entertainment for Canadian audiences during the Second World War, and the Canadian Broadcasting Corporation (CBC) used the art form to distribute propaganda and garner support for the Canadian war effort. Similarly, CBC radio drama became an essential artistic outlet for artists and composers to articulate their political beliefs to a national audience. This article frames Canadian composer John Weinzweig's works for the CBC radio drama series New Homes for Old (1941) within the socio-political climate of the 1930s and 1940s and suggests that radio drama provided Weinzweig with a national soapbox for his radical socialist ideals during a time of political upheaval.

My research draws on archival materials from Library and Archives Canada, the CBC Music Library Archives, and Concordia's Centre for Broadcasting and Journalism Studies to build upon the biographical work of Elaine Keillor and Brian Cherney. I establish Weinzweig's socialist ties and argue that his political leanings prompted him to simplify his serial language in favour of a simplified modernist aesthetic, which appealed to Canada's conservative wartime audiences. This study of Weinzweig's radio works reveals how the composer desired to make serial compositions accessible and palatable, and shows how he incorporated vernacular idioms such as folk songs and national anthems as foils to the elitist European serial aesthetic. In doing so, I show how Weinzweig uses a powerful and pervasive medium to promote his unique compositional style and also to reflect the cultural, political, and aesthetic ideals of leftist socialism.
\end{abstract}

\title{
RÉSUMÉ
}

Le drame radiophonique était le divertissement par excellence pour le public canadien pendant la deuxième guerre mondiale. La Société Radio-Canada (SRC) en a profité pour utiliser cette forme d'art à des fins de propagande et pour stimuler le soutien à l'effort de guerre. Semblablement, la dramaturgie radiophonique de la SRC est devenue une tribune essentielle permettant aux artistes et compositeurs d'exprimer à l'échelle nationale leurs convictions politiques. Cet article remet dans son contexte sociopolitique des années 1930 et 1940 le travail du compositeur canadien John Weinzweig pour la série dramatique de la SRC intitulée New Homes for Old (1941). On y propose que le drame radiophonique a offert à Weinzweig une tribune nationale à l'expression de ses idéaux socialistes radicaux pendant une période de bouleversement politique. Notre recherche prend le relais des travaux biographiques d'Elaine Keillor et Brian Cherney et s'appuie sur des documents d'archives de Bibliothèque et Archives Canada, des Archives musicales de Radio-Canada et du Concordia Centre for Broadcasting and Journalism Studies. Nous confirmons les liens de Weinzweig avec les milieux socialistes et nous avançons que ses sympathies politiques l'ont amené à simplifier son langage en faveur d'une esthétique moderne simplifiée, plaisant davantage au public conservateur 
canadien de ce temps de guerre. Notre étude de l'œuvre radiophonique de Weinzweig montre comment ce dernier a cherché à composer une série d'œuvres faciles d'accès, et comment il a intégré dans son langage musical des éléments plus courants tirés de chansons traditionnelles et d'hymnes nationaux pour lui donner un vernis davantage en phase avec l'esthétique européenne élitiste. Nous montrons en conséquence comment Weinzweig a utilisé un média puissant et omniprésent afin de promouvoir son style musical original et de diffuser les idéaux culturels, politiques, et esthétiques de la gauche socialiste.

\section{BIOGRAPHY}

Carolyne Sumner is a PhD student in musicology at the University of Toronto. She completed her MA Musicology at the University of Ottawa in 2016, and obtained her BA in 2014 from the same institution. Her master's thesis, "John Weinzweig, Leftist Politics, and Radio Drama at the CBC during the Second World War," explores the rise of radio drama in Canada and critically examines how Weinzweig's work for $\mathrm{CBC}$ radio drama became an outlet for his leftist politics. Carolyne's current doctoral research investigates the significance of musical networks in Canada during the post-centennial period and is concerned with the role played by cultural policymakers and gatekeepers in the outcomes of these networks. 